\title{
Minimum Subsistence Allowance and Family Taxation: Examining of the Efficiency Comparison with Some Country Experiences and Turkish Case
}

\author{
Assosiation Prof. PhD. Osman Fatih Saraçoğlu \\ Gazi University, Faculty of Economics and Administrative Science, Department of Public Finance, \\ Incitaşı St, No.4, Postal Code: 06500, Beşevler/Ankara/Turkey

\section{Assosiation Prof. PhD. Eren Çaşkurlu} \\ Gazi University, Faculty of Economics and Administrative Science, Department of Public Finance, \\ Incitaşı St, No.4, Postal Code: 06500, Beşevler/Ankara/Turkey \\ Email:erencas@gmail.com
}

\section{Assistan Prof. PhD. Haydar Lütfü Ejder}

Gazi University, Faculty of Economics and Administrative Science, Department of Public Finance, Incitaşı St, No.4, Postal Code: 06500, Beşevler/Ankara/Turkey

\section{Doi:10.5901/mjss.2014.v5n2p525}

Abstract

Equitable taxation may be the one of much important target for the less developed countries. In those countries' living and working conditions are under certain limits. So tax reforms should include many implementations in which could be provided horizontal equity and encouraging for labour and family. There are many ways to achieve these goals in taxation. Two of them are tax credits and allowances. Especially minimum subsistence allowance is a unique implementation for equitable taxation with ability to pay criterion and family taxation, family tax credits as well. The practice of minimum subsistence reduction was not brought to the fore because of financial reasons in particular in Turkey, while amendments were being carried out in tax laws, this issue was not touched upon, which can be reforming (in case of comprising significant amounts). In other words, handling the issue with its financial aspect led to its withdrawal from the agenda, its social aspect was not taken into consideration. In this paper it is investigated the efficiency of these implementations.

Keywords: Ability to pay criterion; equitable taxation; family taxation; minimum subsistence allowance; poverty threshold

\section{Introduction}

Impartial taxation in generation of tax structure, to wit, tax burden being the same for everybody, and reflection of social preferences, to wit, the implementation of the principles of justice and equality in tax, are the subject of discussion. Just distribution of tax burden among liable is considerably important. In this respect, thorough and accurate comprehension of tax payment capability is required. One of the benefited techniques in terms of being able to comprehend tax payment capability is the minimum subsistence reduction (deduction).

Resting on the power of sovereignty, the state has the authority for taxation. Besides collecting taxes, it can call for some other sacrifices in emergencies as well. Nevertheless, the state should not demand sacrifices that can put lives of its citizens in danger or push them into poverty; it can provide necessary income for them to preserve their health and capabilities for work (Tekeli 1960: 85). The minimum subsistence reduction is the leaving the portion of incomes obtained by people, which corresponds to necessary expenses that they must spend to be able to sustain, out of taxes.

In this study, the practice of minimum subsistence reduction in Turkey is going to be assessed by analyzing it in terms of its form of implementation and efficiency.

\section{Determination of Its Significance and Sum in terms of Tax Payment Capability}

Collecting the tax in respect of solvency (payment capability) entails that tax burden should be justly distributed among liable and liable should not be put into trouble (Akdoğan 1999: 195). Albeit there does not exist the possibility to exactly 
determine tax payment capability, when collecting taxes on income, instruments such as miscellaneous reductions, tax rates and discrimination principle are utilized (Akdoğan 1999: 198). One of the said reductions is the minimum subsistence reduction.

The minimum subsistence reduction refers the non-taxation of income that is required for individuals to be able to sustain himself/herself and his/her family in a minimum extent (Akdoğan 1999: 204). Because, the acceptance of that there is no solvency in this level of income is the case. In the literature on family taxation, there is a kind of and most favoured approach about two person household. Most favoured because a heavily taxation might be possible than singles. According to this, partners are accepted as having different specialization. So one of the partners takes place in division of labour as supplier in labour markets. Other produces goods and services within the home. But the main problems exist within this approach are a taxation of couples versus singles and a tax bias against of support getting married. Horizontal equity criterion requires that a lower tax burden on a couple than on a single (Cigno et al. 2011: 203).

Tax payment capability will ever be the case when the level of income that can subsist liable existence will be exceeded. In this respect, it can be stated that the ones, whose material resources are only enough for sustaining his/her physiological existence, do not have tax payment capability and consequently, they should be left out of tax (Dikmen 1956: 1). Put it differently, it should be kept in mind that expenses spent for the need for food, clothing and shelter in terms of being able to sustain is necessary for being able to produce (Kızlyallı 1969: 311). Consequently, a subsistence reduction, which is at the level of meeting the said expenses, should be entitled. Otherwise, a taxation that leads to decrease of such expenses may bring about dropping of national production in oncoming periods (Kızlyallı 1969: 311).

Considering the ones, whose income that he/she obtains is insufficient to sustain himself / herself in minimum extent, cannot be liable, it can be stated that the minimum subsistence reduction indicates the initial point of liability (Feyzioğlu 1978: 53). Above all, minimum need incorporates physical requirements and although it can vary depending on time, long-term needs are cardinal (Franklin 1971: 3). In other words, which needs are necessary in terms of sustaining minimum level of subsistence is controversial and these needs can be referred as physiological and social (cultural etc.) needs.

Accurately designating the amount of minimum subsistence reduction entails to find the necessary amount of expense for necessary needs to the extent that is sufficient to sustain everyone's life; value measurement that political power possesses regarding the just distribution of tax burden determines the extent of reduction (Bulutoğlu 1978: 198199). However, in addition to the fact that the scope of necessary needs varies person to person, it also varies in time. Therefore, in practice, it can be denoted that the amount of minimum subsistence reduction should be designated as a general amount.

Acceptance of an appropriate amount of minimum subsistence reduction first entails the existence of a healthy tax base (Özbalcı 1983: 188). Besides, while liable are entitled the right to minimum subsistence reduction as a requirement of finance theory, it does not have significance in case of the amount of reduction being quite low and also, it should be kept in mind that it will increase the burden of administration with respect to attending liable jobs, who will benefit from reduction (IIrteş 1979: 6-7). In this respect, first of all, the formation of a healthy tax base and then, determination of the amount of minimum subsistence reduction, which is necessary for people to be able to sustain, in a way that befits human dignity and fulfils necessary needs is required (Alpay 1977: 28).

Establishing the amount of reduction low or high may lead to the deterioration of tax justice. For instance, when reduction amounts are low, as tax justice can breakdown against liable with tight budget and also, when they are high, it can hinder the entry to upper layers of tax rate and diminish its effects of ensuring tax justice (Akdoğan 1980: 28). According to one amongst approaches, justice criterion might not been able to provide, unless a family of which has fewer dependents person, pays lesser tax than from a family of which has a multiple (Lo 2008: 18)

In addition to physiological, social and cultural needs of liable, reduction that it can make in tax proceeds is also effective in determining the amount of minimum subsistence reduction (Feyzioğlu 1978: 54). Besides, personal and physical features and familial condition of liable can be taken into account (1) (Bruce 1998: 488). However, what the amount of reduction should be is a debated issue (the aim of our work on this issue is beyond debate, so check for details in Dikmen 1956: 42-56; Nadaroğlu 1992: 328-29; Tuncer 1975: 316-17) and it was not possible to find an objective criterion that everyone can accept in this respect. We are not entering discussions here, but views regarding what the amount of minimum subsistence reduction should be will be just touched upon:

- According to physiological minimum subsistence reduction view, people, whose material resources are only enough for sustaining their physiological existence, do not possess tax payment capability, the portion over this amount constitutes tax payment capability. Yet, tax payment capability can be mentioned only after enabling the continuance of physiological existence (Akdoğan 1980: 27). However, detecting the amount that 
is needed for sustaining physiological existence cannot be possible due to the fact that it can vary with respect to factors such as age, gender, race and climate (Nadaroğlu 1992: 328). Consequently, determining a general amount of reduction as the minimum subsistence reduction might be resorted.

- In cultural minimum subsistence reduction view, designating a reduction amount with respect to levels of living of various social classes is required. However, it can be argued that establishing different amounts of minimum subsistence reduction for various social classes such as workers, peasants, merchants and industrialists is not possible, and also, resorting to such practice will create great difficulties due to the fact that designating such amount is not appropriate for social justice and tax technique (Nadaroğlu 1992: 328).

\section{Some Countries Experiences and Turkey Application}

\subsection{Minimum Allowance Implementation in Some Countries}

Several countries have initiated or expanded a range of policies aimed at supporting working families on low income (Anderberg 2008: 499). Minimum allowance implementations vary significantly in many countries, but serve the same purpose. For example, US Earned Income Tax Credit (EITC) only offers benefits to households with at least one working adult (Anderberg 2008: 499). Encouraging labour supply to struggle poverty, this strategy is mostly useful as well as the formation of two-parent households (Anderberg 2008: 500). On the other hand, as UK tax system is mostly individuallybased, it is possible that there is generated negligible incentive for or against partnership. Allowance is given for the possibility that some partner (especially woman) would change their labour force participation status and for nonlinearities in the assignment of partner characteristics and labour supplies (Anderberg 2008: 501). Working Families' Tax Credit (WFTC) reform strengthened the benefit incentives for having a partner or at least reduced the benefit disincentives for having a one (Anderberg 2008: 525). For working families with children, the tax credit is called as the child tax credit and besides that for low-paid people the working tax credit is available (Ridge and Millar 2011: 87). These credits both are so important and vital for especially mother worker because they are ensuring a steady and reliable income and security of income in employment for these mothers (Ridge and Millar 2011: 93 - 5).

In Table 1 between the terms $2007-08$ and 2009 - 10 the most developing value is the child element credit with 21 percent. Also according to the changing's in the single / couple guarantee value between the same periods, there is a little advantage for couples with 9, 4 percent.

Table 2 shows that some OECD countries' minimum allowance and family taxation status. As seen at values, especially minimum allowance and child allowance (in some country it is called as family allowance) are the most regarding policy tools. Despite little differences in some points, there is much other country except OECD countries, which benefits from the implementations awards. For example, China is a country for the minimum subsistence allowance implementation in which the most of taken into account. Basic Living Allowance (BLA) scheme in China is designed to guarantee the minimum living of the entire needy person by government through the regularly and quantitative allowances (Xingqing and Shunxi 2007: 3). The concept of "needy person" refers; the persons who have no income and their allowances should be according to the line and the persons who have some income and their allowances should be the margin between their income and the threshold (Xingqing and Shunxi 2007: 10). The guarantee measures include regular and ration allowance and other supplement measures (Xingqing and Shunxi 2007: 17).

Differences among countries may affect efficiencies of the minimum allowance implementations and creates different tax burden levels according to family status.

Tax burden may vary depending on many factors. However there is an important factor that taxing wages and tax allowances which are made depending on family status. According to a family which has one earner couples and two children, in graphic 1 between 2000 - 10 the tax burden values shows that some countries as Greece and Mexico are the most having tax burden in that situations, Germany and the USA, while the opposite case.

Also in graphic 2, tax burden values are shown depending on the family status. But this time there is two earner couples and two children, nevertheless one of the couple is faced with lower taxation. While Greece maintains own position, as surprisingly seen Mexico is the country with the lowest level under these circumstances.

As mentioned before justice criterion in taxation refers that heavily taxation or tax burden after taxation should be on individuals whose have a proper ability to pay. Graphic 3 shows that according family status, less than the countries are consistent with the fair taxation. But can be said that this situation is appropriate to the income effect of taxation.

In most of the countries especially in UK the household taxation problem was tried to solve by carrying out a fixed 
deduction from total gross income name as "married man's allowance". This approach may be applied by three different ways (Cigno et al. 2011: 203-4):

- If couples each earn one half of the total income, this amount (total income) will be taxed at progressive marginal rates. This way is called as joint taxation. Tax rate in this way on the last dollar of the one partner's income is applied to the first dollar of the other's.

- In the individual taxation system, each partner's income taxes separately.

- In the selective taxation, one of the partner's incomes is taxed on a separate, lower, progressive tax schedule than others.

In real time implementations, child-related subsidies and tax breaks combine to make a household's net tax bill dependent on their dependents. However the logic of these benefits and allowances is not on purpose of examining the household but is to either compensate parents for the cost of having children, or to transfer resources to the children themselves (Balestrino et al. 2002: 176). Some empirical works show that taxes are important economic policies that can influence the fertility decision (Baughman and Conlin 2009: 540). For that purpose, Canada imposes tax policies that are more explicitly targeted child benefits (Baughman and Conlin 2009: 540).

\subsection{Minimum Allowance Implementation in Turkish Tax System}

Provisions aimed at the state's provision and protection of work conditions are presented in the article 49 of the Constitution of the Republic of Turkey and provisions regarding taxation in respect of solvency are presented in the article 73. Therefore, leaving the ones without any tax payment capability out of tax should be resorted to support working life and ensure economic development.

The minimum subsistence reduction came into force in 1950 in Turkey and while in the first years, it was beneficial considering that its amount was close to reality, but in time, it became non-reflective of conditions of the time and it was chosen to be abolished instead of adapting it to the changing conditions (Taş 1991: 51). The name of the minimum subsistence reduction was changed into general reduction via the Law no. 2361 that came into effect as of 1.1.1981 and it kept on implemented as general and special reduction.

As of 1986, implementation of special reduction only intended for wage-earners was given a place. This practice only intended for wage-earners was abolished at the end of 2003. Owing to the fact that special reduction is only aimed at wage-earners in respect of scope, it is not a form of implementation of minimum subsistence reduction but discrimination principle.

Special expense reduction that was implemented with the purpose of proliferation and establishment of document order to shrink informal economy was revoked as from 1.1.2004. Institution of tax refund to wage-earners was put into effect as from 1.1.2004 with the aim of compensating the gap emerged because of abolishment of special expense reduction and special reduction and satisfying the reactions.

Lastly, the article 31 of the Law No. 5165 and the repeated article 121 of Income Tax Law, in which tax deduction in wage earners was regulated, were revoked as from 01.01.2007. In a sense, minimum subsistence reduction was brought as coming into effect when the legislation was issued to be implemented on incomes that will be acquired as of 1.1.2008 again by the Law No. 5165 for the purpose of compensating the loss of wage-earners resulting from the abovementioned revocation in a way.

In the ground of the legislation, the minimum subsistence reduction is explained as discrimination principle being included in the system. But, in tax theory, discrimination principle entails that incomes provided by labour are taxed at lower rates than fortune and capital incomes by taking the resource, of which the income is acquired, into account. The minimum subsistence reduction appears as a common practice incorporating all liable as explained above. Therefore, for starters, the name of the practice is misexpressed.

The minimum subsistence reduction put into effect as the article 32 of Income Tax Law and the Law No. 5165 is a deduction that will be applied in taxation of payment in actual method. A standard deduction is brought for the liable itself; his/her unemployed spouse without any income and his/her children, whom he/she is obliged to fend for, by relating to minimum wage in the system of minimum subsistence reduction entered into force to be applied on incomes acquired as from 1.1.2008.

The amount of minimum subsistence reduction is determined resting on minimum wage. Its amount differentiates with respect to whether spouse (2) works or not and the number of children (3).

The amount of minimum subsistence reduction is;

- $50 \%$ for the liable himself/herself, 
- $10 \%$ for his/her unemployed spouse without any income,

- $7.5 \%$ for the first two children

- $5 \%$ for other children for the annual gross amount of minimum wage implemented for workers, who are bigger than 16 working in industrial sector, and in force at the beginning of calendar year, in which the wage is acquired.

In case of the income belonging to partial period, deduction amounts that correspond to this period are predicated on by counting fractions of month as full month.

Accordingly, the amount of minimum subsistence reduction in terms of the ones, who are married with two children and whose spouses are unemployed, under today's conditions (the gross amount of minimum wage $=796.50 \mathrm{TL}$ ) is 597.375 TL in total including;

- $\quad 398.25$ TL for the liable himself/herself,

- $\quad$ 79.65 TL for his/her unemployed spouse without any income,

- $\quad 119.475$ TL for the first two children.

The portion that will be found by applying the percentage (15\%) corresponding to the first layer of income tax rate of this amount is the amount that will be offset from tax; it is (597.375 x 15\% =) 89,60 TL per month and 1.075,2 TL annually.

As it is seen, no matter how much the income is, deduction amount is the same for all wage-earners, who has the same marital status. That is, tax advantage provided by the minimum subsistence reduction is not affected by wage level. It should not be forgotten that refund amount, which can be received in parallel to the increase of amount of wage, increases in the tax deduction system, which was the previous practice.

When determining reduction amount, the marital condition and familial situation of the liable in the time when the income was acquired is predicated on. Changes that will occur against the liable during the year are taken into account as of this particular date. Deduction is applied to income of only one of spouses for children as separately for each individual in the family, who attains income. For those, who got divorced, the number of children, for whom they provide child support, is taken into consideration in calculation of deduction amount.

The minimum subsistence reduction is as stated above and it is implemented by means of offsetting the amount found by multiplication of the ratio applied to the first income layer of income tax rate in the article 103 of Income Tax Law. In case of that the portion that will be offset is too much, refund is not performed. That is to say, due to the fact that the amount that will be offset cannot be more than tax calculated over wage, the practice of minimum subsistence reduction, consequently, tax refund will not be the case.

Compatibility of the minimum subsistence reduction amounts to today's conditions carries weight, in this respect, the Council of Ministers is authorized. The Council of Ministers is vested with increasing or deducing the minimum subsistence reduction amounts up to its legal ratio provided that its sum shall not exceed the annual gross amount of minimum wage.

\section{Concluding Remarks}

It is seen that with the implementation of minimum subsistence reduction, when it is compared with tax deduction, which was annulled by indicating it as its alternative, both applications are different as both amount and function. The minimum subsistence reduction can be assessed in terms of realism of reduction amounts that it provides to liable and how much tax loss that it can cause for the state.

Although the minimum subsistence reduction is an essential instrument in grasping tax payment capability, it relatively reduces tax burden on only wage-earners with low income with its current state and it is far from realizing the objectives. Considering a married liable with two children, whose spouse is unemployed, it is seen that the encountered amount of $89.60 \mathrm{TL}$ is not a realistic amount.

As shown in table 3 , while the hunger threshold (4) is $889.54 \mathrm{TL}$, the poverty threshold (5) is $2.897,54$ according to the outcomes of researches conducted by Turk-Is regarding February 2011.

In Turkey, where the hunger threshold is $889.54 \mathrm{TL}$ and the poverty threshold is $2.897,54$, the minimum subsistence reduction amount being $10 \%$ of the hunger threshold and about $3 \%$ of the poverty threshold indicates how insufficient it is.

There are 11 million wage-earners in Turkey and setting off from minimum wage valid in January 2011, cost of the minimum subsistence reduction to the state or the amount of tax that the state gave up collecting due to the minimum subsistence reduction can be superficially calculated as well. 
The amount of deduction that a married wage-earner with two children, whose spouse is unemployed, can benefit from is 89.60 per month and 1.075,2 per annum. Setting off from this, it can be stated that an approximate amount of 11.827.200.000 TL is realized as minimum subsistence reduction in terms of 11 million wage-earners.

The practice of minimum subsistence reduction was not brought to the fore because of financial reasons in particular in Turkey, while amendments were being carried out in tax laws, this issue was not touched upon, which can be reforming (in case of comprising significant amounts). In other words, handling the issue with its financial aspect led to its withdrawal from the agenda, its social aspect was not taken into consideration.

The practice is only effective with regard to being intended for wage-earners and meeting the necessities of discrimination principle. It is seen that this practice is an insufficient application both with regard to the compatibility to current conditions, being an alternative of tax refund for wage-earners and realism.

\section{Notes}

1. Given the personal characteristics; age and marital status of taxpayers are taken into account. In addition to this, characteristics of physical and family are also taken into account. In this regard, for example, minimum subsistence allowance, discount rates for married couples could be more than from the rates for whose unmarried person. In addition, according to the principle of tax justice, family support and child benefits can be applied. Indeed, in many countries, the subsistence allowances for married taxpayers can more than double those for singles.

2. The concept of "spouse" refers to individuals who had a marriage bond between them.

3. The concept of "child" refers to the person who lives with taxpayers (parents) and is under age 18. With pre acceptance of the term of receiving full time education, person who lives with parents and is under age 25 is also accepted as child.

4. Hunger threshold includes, minimum costs of food of a four persons family. Hunger threshold is determined through the minimum set of calories was determined by the World Health Organization of working people, his wife, (0-6) and (15-19) age groups.

5. Poverty threshold is determined by compulsory expenditures which are included clothing, health, housing and education.

\section{References}

Akdoğan, A. (1980), Gelir Vergisi Açısından Vergi Adaletine Teknik Bir Yaklaşım, A.I.T.I.A. Maliye Fakültesi, Maliye ve Vergi Hukuku Enstitüsü Yayınları, No.137/1- 9, Ongun Kardeşler Matbaacılık Sanayii, Ankara.

Akdoğan, A. (1999), Kamu Maliyesi, 7. B., Gazi Kitabevi, Ankara.

Alpay, A. (1977), "En Az Geçim İndirimi Sorununa Bir Yaklaşım", Mali Hukuk Dergisi, Sayıştay Denetçileri Derneği Yayını, S. 47.

Anderberg, D. (2008), "Tax Credits, Income Support, And Partnership Decisions", International Tax and Public Finance,15: 499-526

Balestrino, A., Cigno, A. and Pettini, A. (2002), "Endogenous Fertility and the Design of Family Taxation", International Tax and Public Finance, 9, 175-193, 2002.

Bruce, N. (1998) Public Finance and The American Economy, Addisson - Wesley Publications, New York.

Bulutoğlu, K. (1978), Türk Vergi Sistemi, C. 1, 6. B., Fakülteler Matbaası, İstanbul.

Cigno, A., Pestieauy, P. and Rees R. (2011), "Introduction to the Symposium on Taxation and the Family", CESifo Economic Studies, Vol. 57, 2/2011, 203-15

Dikmen, O. (1956), Asgari Geçim Indirimi, İstanbul Üniversitesi, İktisat Fakültesi Maliye Enstitüsü Yayınları, No. 693/92-3, Sermet Matbaası, İstanbul.

Dikmen, O. (1958), "Asgari Geçim Haddi Üzerine Düşünceler", Maliye Enstitüsü Konferansları, 2. Seri, Yıl 1956, İstanbul Üniversitesi, İktisat Fakültesi Maliye Enstitüsü Yayınları, No. 758/98-4, Sermet Matbaası, İstanbul.

Feyzioğlu, B. (1978), "Gelir Ve Kurumlar Vergilerinde Muafiyet Ve İstisnalar", Vergi Sorunları Dergisi, S. 1978/I.

Franklin, N. N. (1971), (Trans. Taşçıŏlu, Muharrem), "En Az Geçimin Anlamı Ve Ölçülmesi", Uluslararası Görüşler Açısından Endüstri ve Tarım Sektörlerinde Asgari Geçim, Asgari Ücret Sorunları ve Bu Konular Karşısında Türkiye, Tisa Matbaacılık Sanayii, Ankara.

İrteş, A. (1979), "Asgari Ücret, En Az Geçim İndirimi, Çocuk Zamları Ve Aile Yardımı Nedir, Ne Olmalıdır", Mali Hukuk Dergisi, Sayıştay Denetçileri Derneği Yayını, S. 58, Eylül.

Kızılyallı, H. (1969), Türk Vergi Sisteminin Ekonomik Analizi, Ankara Üniversitesi S.B.F. Maliye Enstitüsü Yayınları No: 286/33, Sevinç Matbaası, Ankara.

Nadaroğlu, H. (1992), Kamu Maliyesi Teorisi, 8. B., Beta Basım Yayım Dağııım A.Ş., Yayın No. 337/17, İstanbul.

Özbalıı, Y. (1983), Gelir Vergisi Kanunu Yorum ve Açıklamaları, Feryal Matbaacılık, Ankara. 
Reagan Baughman, R., Conlin, S. D. (2009), "The Earned Income Tax Credit And Fertility", Journal of Population Economics, 22: 53763

Sinclair, W., Lipkin, B. (2009), Tax Guide 2009 - 2010, St. James's Place Wealth Management, Palgrave MacMillan, UK.

Taş, M. (1991), "Ödeme Gücü İlkesi Açısından Türk Gelir Vergisi'nin Kısaca Değerlendirilmesi", Banka ve Ekonomik Yorumlar Dergisi, S. 6 .

Taxing Wages, (2011), 2009-2010 Special Feature: Wage Income Tax Reforms and Changes in Tax Burdens 2000-2009, OECD.

Tekeli, E. (1960), "En Az Geçim İndirimi ve Aile Tahsisatı", Sosyal Siyaset Konferansları, 9-10-11. Kitap, İstanbul Üniversitesi İktisat Fakültesi İktisat ve İçtimaiyat Enstitüsü Neşriyatı No. 854/115-28, Fakülteler Matbaası, İstanbul.

Tess Ridge, T., Millar, J. (2011), "Following Families: Working Lone-Mother Families and their Children", Social Policy \& Administration, Vol. 45, No. 1, February, pp. 85-97

Tuncer, S. (1975), Kamu Maliyesi, 4. B., Eskişehir ITíA Yayınları No. 41, Yalkın Ofset Matbaası, İstanbul.

Vance Kuang-Ta Lo, V. K. (2008), "An Introduction to the Alternative Minimum Tax-By International Comparisons", Paper given at International Symposium: Recent Development in Taiwan's Taxation, Japan, 26 January 2008, http://www.ipp.hitu.ac.jp/EastAsianTaxForum/PDF/Kuang-taLo-An\%20Introduc tion\%20to\%20Alternative\%20Minimum\%20Tax.pdf.

Worldwide Tax Summaries, (2011), PricewaterhouseCoopers, http://taxsummaries.pwc.com /uk/taxsummaries, Access date: 14.06.2011.

Xingqing, Y., Shunxi, Z. (2007), "Evolvement Process and Actuality of the Basic Living Allowance (BLA) Scheme in China's Urban and Rural Areas", Paper given at IFPRI 2020 Conferences, Beijing, China, October 17 - 19 October, http://conferences.ifpri.org /2020Chinaconference/pdf/ 015YeXingqing.pdf, (Access date: 12.05.2011)

\section{Tables and Graphics}

Table 1: The UK Tax Credit System Compared with the Old Ones

\begin{tabular}{|l|c|c|c|}
\hline & $2007-08$ & $2008-09$ & $2009-10$ \\
\hline & $£$ & $£$ & $£$ \\
\hline CTC: Family element & 545 & 545 & 545 \\
\hline Baby addition & 545 & 545 & 545 \\
\hline Child element & 1,845 & 2,085 & 2,235 \\
\hline Disabled child element & 2,440 & 2,540 & 2,670 \\
\hline Severely disabled child element & 980 & 1,020 & 1,075 \\
\hline WTC: Basic element & 1,730 & 1,800 & 1,890 \\
\hline Couples and lone parent element & 1,700 & 1,770 & 1,860 \\
\hline 30 hour element (for couples - both must work 30 hours & 705 & 735 & 775 \\
\hline jointly with one working at least 16 hours each week) & 2,310 & 2,405 & 2,530 \\
\hline Disabled worker element & 980 & 1,020 & 1,075 \\
\hline Severe disability worker element & \multicolumn{3}{|l|}{} \\
\hline Childcare element: & 9,100 & 9,100 & 9,100 \\
\hline For 1 child & 15,600 & 15,600 & 15,600 \\
\hline For 2 or more children & $80 \%$ & $80 \%$ & $80 \%$ \\
\hline Percentage of eligible costs covered & \multicolumn{3}{|l}{} \\
\hline PC: Standard minimum guarantee per week: & 119.05 & 124.05 & 130 \\
\hline Single & 181.7 & 189.35 & 198.45 \\
\hline Couple &
\end{tabular}

Source: Walter SINCLAIR and Barry LIPKIN, Tax Guide 2009 - 2010, St. James's Place Wealth Management, Palgrave MacMillan, UK, 2009, 19.

Table 2: Minimum Allowance and Child Allowance Values in Some OECD Countries 2010

\begin{tabular}{|c|c|c|c|c|c|c|}
\hline & $\begin{array}{c}\text { No taxable income/ } \\
\text { Basic Relief / Minimum } \\
\text { Allowance }(€)\end{array}$ & $\begin{array}{c}\text { Special } \\
\text { Allowance } \\
(€)\end{array}$ & Child Credit $(€)$ & $\begin{array}{c}\text { Child Allowance / Family } \\
\text { Allowance }(€)\end{array}$ & $\begin{array}{c}\text { Spouse } \\
\text { Allowance } \\
(€)\end{array}$ & $\begin{array}{c}\text { Special } \\
\text { Explanations } \\
(€)\end{array}$ \\
\hline Austria & 11.000 & 60 & $220 / 132(\mathrm{per})$ & $\begin{array}{c}1.370(1 \mathrm{chl}) / 1.536(2 \mathrm{chl}) / \\
1.825(3 \mathrm{chl}) / 2.200(4 \mathrm{chl})\end{array}$ & - & - \\
\hline Canada & 1.121 & - & 227 & $\begin{array}{c}5.040(0-7 \mathrm{age}) / 2.880(7-16 \\
\text { age })\end{array}$ & 1.121 & - \\
\hline
\end{tabular}




\begin{tabular}{|c|c|c|c|c|c|c|}
\hline Denmark & 205 & - & - & \begin{tabular}{|c|}
552 (0-2 age) / 398 (3-6 age) / 344 \\
(7-17 age)
\end{tabular} & - & - \\
\hline France & 5.875 & 415 (min) & $\begin{array}{l}1.494 \text { (up to } 2 \\
\text { child) / } 1.914 \text { ( } 3 \\
\text { child and more) }\end{array}$ & 16.125 & - & - \\
\hline Germany & 920 & 35 & 7.008 & $\begin{array}{l}2.208 \text { (up to } 2 \text { child) / } 2.280 \text { ( } 3 \\
\text { children) / } 2.580 \text { ( } 4 \text { children) }\end{array}$ & - & - \\
\hline Greece & 12.000 & - & a & $\begin{array}{c}1.500 \text { ( } 1 \text { child }) / 3.000 \text { (2 children }) / \\
11.500 \text { ( } 3 \text { children }+2.000 \text { per } \\
\text { extra })\end{array}$ & $b$ & $a+b=17.524$ \\
\hline Hungary & 45 & - & - & 37 (min) / 78 (max) & - & - \\
\hline Mexico & 293 & - & - & - & - & - \\
\hline New Zealand & 3.557 & - & $4.362 / 1.796$ & 11.975 & - & - \\
\hline United Kingdom & 7.226 & - & $\mathrm{k}$ & 5.133 & $\mathrm{~m}$ & $k+m=5.741$ \\
\hline United States & 7.866 & - & 690 & $\begin{array}{c}2.104 \text { (1 child) / } 3.476 \text { ( } 2 \text { children) } / \\
4.047 \text { ( } 3 \text { children }\end{array}$ & 2519 & - \\
\hline
\end{tabular}

Source: Worldwide Tax Summaries, PricewaterhouseCoopers, http://taxsummaries. pwc.com /uk/taxsummaries, Access date: 14.06.2011; Taxing Wages, 2009-2010 Special Feature: Wage Income Tax Reforms and Changes in Tax Burdens 2000-2009, OECD, 2011.

Table 3: Hunger and Poverty Threshold of A Family of Four (TL/Month)

\begin{tabular}{|l|c|c|}
\hline & January 2011 & February 2011 \\
\hline Adult Worker & 238,60 & 247,41 \\
\hline Adult Woman & 202,34 & 207,00 \\
\hline Child in the Age Group of 15-19 & 255,80 & 260,71 \\
\hline Child in the Age Group of 4-6 & 173,63 & 174,42 \\
\hline Hunger Threshold & $\mathbf{8 7 0 , 3 7}$ & $\mathbf{8 8 9 , 5 4}$ \\
\hline Poverty Threshold & $\mathbf{2 . 8 3 5 , 0 8}$ & $\mathbf{2 . 8 9 7 , 5 4}$ \\
\hline
\end{tabular}

Source: http://www.turkis.org.tr/?wapp=52521E5F-FCA5-4BDD-940D-A284DA6F151D (Access Date: 19.03.2011)

Graphic 1: Evolution of the tax burden 2000 - 10 One-earner married couple with two children at $100 \%$ of average earnings Income Tax as a \% of gross wage earnings (percentage change)

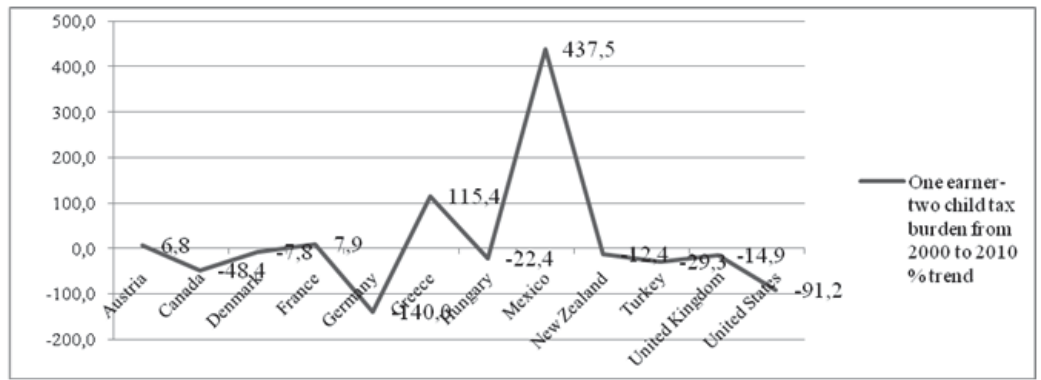

Source: Taxing Wages, 2009-2010 Special Feature: Wage Income Tax Reforms And Changes In Tax Burdens 20002009, OECD, 2011, 178. It is own calculation.

Graphic 2: Evolution of the tax burden, 2000-2010 Two-earner married couple with two children, one at 100\% average earnings and the other at $33 \%$ Income Tax as a $\%$ of gross wage earnings (percentage change) 


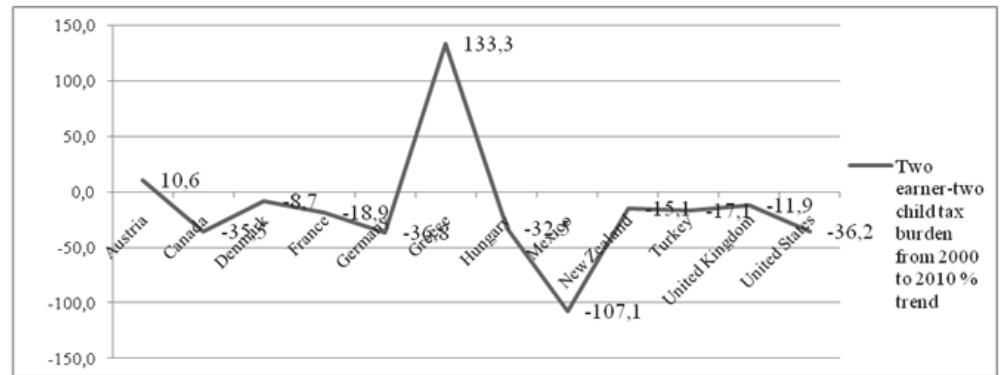

Source: Taxing Wages, 2009-2010 Special Feature: Wage Income Tax Reforms And Changes In Tax Burdens 20002009, OECD, 2011, 181. It is own calculation.

Graphic 3: Comparison with the Two Dimensional Groups of Tax Burden 2010

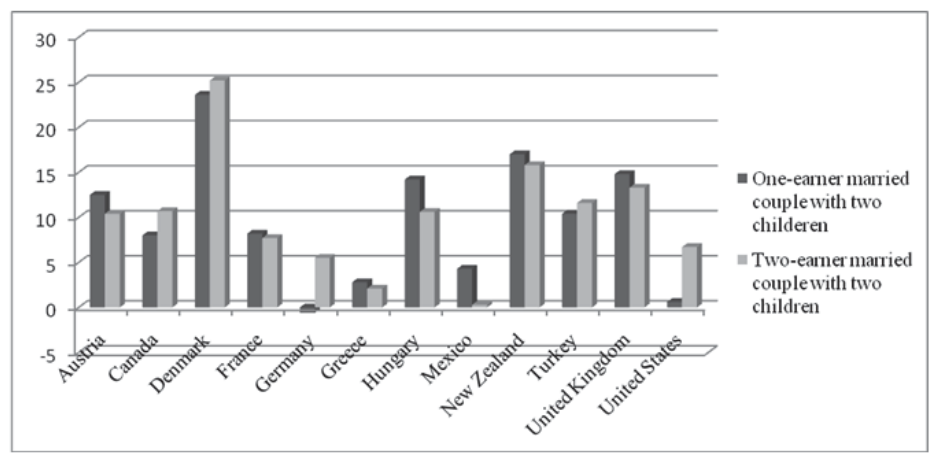

Source: Taxing Wages, 2009-2010 Special Feature: Wage Income Tax Reforms And Changes In Tax Burdens 20002009, OECD, 2011, 178 - 81. It is own calculation. 
